\title{
HUBUNGAN ANTARA KECERDASAN EMOSIONAL DAN DEPRESI PADA IBU YANG MEMILIKI ANAK DENGAN GANGGUAN AUTISME
}

\author{
Melianl \\ Jenny Lukito Setiawan \\ Monique Elizabeth Sukamto \\ Universitas Surabaya
}

\begin{abstract}
Mothers usually expect their children to grow well and healthy. Therefore, having an autistic child is a very difficult experience as this may make mothers fool frustrated and sad. Continuous negative feelings could make the mothers feel depressed. This study aims to examine the corrolation between emotional intelligence and depression on mothers with an autistic child. Twenty-six mothers (27) with an autistic child below 12 years old participated in the study by filling in the questionnaires of emotional intelligence and depression. Data were then analyzed statistically by using the Product Moment Correlation Test. Findings showed that there was a significant negative correlation between emotional intelligence and deprossion $(r=-0.571, p<0.05)$ The findings suggest that the higher the emotional intelligence a mother has, the lower the depression level she experiences. Findings also show the indication of association between work status and depression on mothers with an autistic child. The implications of the findings are explared further.
\end{abstract}

Keywords: autism, emotional intelligence, depression

\section{Pengantar}

Hasil penelitian menunjukkan bahwa tingkat prevalensi dari autisme diperkirakan empat sampai lima per 10.000 anak (Safaria, 2005). Beberapa penetitian yang menggunakan definisi luas dari autisme memperkirakan 10 sampai 11 dari 10.000 anak mengalami gangguan autisme. Menurut Chaplin (Kuwanto dan Natalia, 2001). gangguan autisme menyebabkan anak-anak penyandang autisme semakin lama semakin jauh tertinggal bila dibandingkan dengan anak-anak non autisme yang sebaya ketika usia mereka semakln bertambah. Anak-anak autisme belajar jauh lebih sedikit dart lingkungannya bila dibandingkan dengan anak nomal. Mereka tidak belajar dengan cara yang sama seperti anak lain seusianya. Anak autisme menunjukkan kegagatan membina hubungan interpersonal yang ditandai dengan kurangnya respon terhadap dan atau kurangnya minat kepada orang-orang atau anak-anak of sekitamya. Kekhususan pada anak autisme adalah sulitnya berkonsentrasi dan memiliki dunia sendiri, sehingga anak sulit berinteraksi dengan lingkungan. Anak autis memiliki cara berpikir yang dikendalikan oleh kebutuhan personal atau diri sendiri, menanggapi dunia berdasarkan penglihatan dan harapan sendiri, menolak realitas dan memillki keasyikan yang ekstrim dengan pikiran dan fantasinya sendiri.

Berbagai macam reaksi emosi yang negatif sudah pasti menyelimuti perasaan orangtua yang mendapati anaknya 
didiagnosis autisme. Syok dan penyangkalan atau perasaan tidak percaya, sedih, cemas, malu, marah merupakan reaksi yang sering dialami (Safaria, 2005). Syok adalah perasaan yang paling umum dan pertama kali dirasakan oleh orang tua ketika anak mereka didiagnosis mengalami autisme. Penyangkalan juga sering muncul karena tidak mempercayai hasll diagnosis. Perasaan yang pasti dialami orangtua adalah sedih mengetahui anak mereka mengalami gangguan autisme. Perasaan cemas juga turut menghantul karena orangtua khawatir akan masa depan anak mereka. Tidak jarang orangtua memunculkan perasaan menolak keadaan tetapi penolakan ini justru membuat orangtua semakin tersiksa. Perasaan malu muncul saat orangtua dihadapkan pada lingkungan sosial. Dari hasil wawancara pada survei awal yang dilakukan peneliti dengan kepala sekolah terapi autisme $X$ diperoleh data bahwa ada beberapa bu yang malu membawa anak mereka yang autisme ke pusat-pusat perbelanjaan atau mal. Ada pengalaman mereka yang membuat mereka malu seperti pegawai toko mengamati anak mereka yang autis dengan pandangan yang aneh atau sinls sehingga membuat si bu harus memarahl pegawai toko. Tidak jarang orangtua merasa minder karena memiliki anak dengan gangguan autisme. Kemarahan juga terkadang menyertai reaksi orang tua dalam menghadapi kenyataan memiliki anak autis. Perasaan marah ini dapat berakibat negatif karena perasaan ini membuat seseorang menjadi peka dan sensitif. Kemarahan yang berlarut-larut akan mengganggu kestabilan emosi atau gangguan suasana hati.

Di samping itu sebagian orang tua mengembangkan reaksi-reaksi depresi, misalnya perasaan tidak mampu, tidak berharga, merasa hidup tidak berarti, perasaan bersalah/berdosa (Safaria, 2005). Perasaan tidak mampu muncul terutama pada ibu karena merasa tidak behasil melahirkan anak yang normal. Perasaan tidak mampu dan perasaan bersalah/berdosa ini dapat mengarah pada kebencian pada diri sendiri. Hal ini membuat orang tua berkeinginan untuk menghukum diri sendiri. Perkembangan anak yang tidak sesuai dengan harapan membuat sebagian orangtua merasa hidupnya tidak berarti. Reaksi-reaksi emosional seperti perasaan benci terhadap diri sendiri, sedih, marah, dan merasa hidupnya tidak berarti yang terus menerus ditekan dapat menyebabkan depresi baik depresi ringan, sedang, atau berat.

Namun persoalan depresi mungkin dapat lebih ringan atau bahkan disingkirkan dan tidak perfu dialami oleh orangtua yang memiliki anak autisme apabila orangtua mampu mengatasi kekecewaan, kegagalan, serta reaksi-reaksi emosional yang muncul. Memang reaksl-reaksi emosional tersebut sangat kuat, namun bukan berarti emosiemosi tersebut tidak dapat dikendalikan. Karena itulah peneliti ingin mengetahui hubungan antara kecerdasan emosional dan depresi pada ibu yang memiliki anak dengan gangguan autisme.

\section{Tin jauan Pustaka}

\section{Depresi}

Kartono dan Gulo (2000) mendefinlsikan depresi sebagai keadaan patah hati atau putus asa yang disertai dengan melemahnya kepekaan terhadap stimuli tertentu, pengurangan aktivitas fislk ataupun mental dan kesukaran dalam berpikir. Menurut Shreeve (1991), depresi adalah gangguan mood, keadaan melankolia yang berkepanjangan yang timbul tanpa alasan yang jelas atau sebagai suatu reaksi yang berfebihan terhadap suatu kejadian. Depresi dapat menghilangkan kegembiraan, hasrat, harapan, ketenangan pikiran, serta kemampuan untuk merasakan kepuasan kerja, hubungan persahabatan dan lingkungan sekitamya.

Sedangkan menurut Greist dan Jefferson (1984) depresi adalah suatu gangguan yang berlangsung cukup lama dan disertai dengan gejala-gejala spesifik yang mengganggu kewajaran sikap dan tindakan seseorang atau menyebabkan kesedihan yang sangat dalam. Gejala-gejala yang menjadi karakteriskik depresi adalah adanya mood depresif seperti sedih, murung, 
kehilangan semangat, dan rasa rendah diri. Bisa jug a muncul gejala hilangnya minat atau rasa senang secara nyata dalam seluruh atau hampir semua aktivitas yang biasanya dilakukan (Safaria, 2005).

Beck (Emmanuell, 2004) juga menyatakan bahwa individu yang mengalami depresi akan menunjukkan perubahan suasana hati yang spesifik seperti merasa kesepian dan apatis. Individu tersebut memiliki konsep difi yang negatif dan memiliki kecenderungan untuk menyalahkan dirl sendiri. Karenanya individu tersebut memiliki keinginan untuk menghukum difi sendiri, menghindar, dan menyembunyikan diri serta mengalami perubahan dalam aktifitas. Selanjutnya Beck (LaHaye, 2005) menjelaskan bahwa tanda-landa atau gejalagejala utama dalam diagnosis depresi adalah keadaan yang terganggu (kesedihan, ketakutan, perasaan tak berguna), penyiksaan diri, tingkah laku merendahkan diri, keinginan untuk mati, munculnya gejalagejala fisik (kehilangan sełera makan, dan berat, tidak dapat tidur), dan pemikiran telah melakukan dosa yang tidak dapat diampuni.

Depresl dapat muncul karena berbagai sebab. Menurut LaHaye (2005), depresl dapat disebabkan oleh kekecewaan, kurangnya harga diri, perbandingan yang tidak adil dan penolakan. LaHaye menjelaskan bahwa kekecewaan atau pengalaman yang tidak menyenangkan merupakan salah satu penyebab depresi. Jarang orang terserang depresi jika segala sesuatunya berjalan sesual keinginan. Salah satu sumber umum kekecewaan di dalam kehidupan di antaranya adalah orang lain, adanya tekanan, kelelahan fisik, serta sebabsebab Jalnnya. Kurangnya harga diri juga dapat menjadi penyebab. Individu dengan harga diri rendah dan perfeksionis cenderung membesar-besarkan harapannya yang tidak tercapai. Depresi dapat terjadi saat seseorang membandingkan dirinya dengan orang lain secara berlebihan, membandingkan kekurangan diri dengan kekuatan atau kelebihan yang dimiliki orang lain. Ketidakpuasan pada diri sendiri dapat mengarahkan pikiran yang nantinya mendatangkan depresi. Penolakan adalah suatu keadaan di mana seseorang menolak hal-hal yang tidak diingini. Depresi semacam ini biasanya dimulai dini sekali atas anak yang tidak diinginkan oleh orangtua.

\section{Kecerdasan Emosional}

Goleman (2000) menyatakan bahwa kecerdasan emosional adalah suatu kecakapan yang meliputi kemampuan mengendalikan diri sendiri (self control), memiliki semangat dan ketekunan (zeal \& persistence), memotivasi diri sendiri (ability to motivate oneself), ketahanan menghadapi frustrasi, kemampuan mengatur suasana hati ( $m o o d$ ), dan kemampuan menunjukkan empati (empathy), harapan serta optimisme. Orang yang dapat mengendalikan emosi, meiuapkan emosinya secara tepat dan memperhatikan serta memikirkan perasaan orang lain dapat dikatakan sebagai orang yang cerdas secara emosional.

Menurut Goleman (2000), kecerdasan emosional terdiri dari lima aspek yaitu kesadaran diri, kemampuan mengelola emosi, kemampuan memotivasi dirl sendiri, kemampuan menunjukkan empati serta keterampilan sosial.

a. Kesadaran Diri. Kesadaran diri adalah kemampuan Individu untuk menyadari dan memahami keseluruhan proses yang terjadi di dalam dirinya, perasaannya, pikirannya, dan latar belakang dari tindakannya. Aspek ini merupakan dasar dari seluruh aspek lainnya. Artinya, kesadaran diri akan membantu tercapainya aspek-aspok yang lain. Dengan memiliki kesadaran diri individu diharapkan dapat mengetahui dan memahami emosiemosi yang muncul dalam dirinya.

b. Kemampuan Mengeloia Emosi. Kemampuan mengelola emosi yaitu kemampuan individu untuk mengeloia dan menyeimbangkan emosi-emosi yang dialaminya, khususnya emosi yang negatif seperti kemarahan, kesedihan, kecewa, dendam, dan kebencian. Kemampuan mengelola emosi-emosi ini akan membuat individu tidak terbawa dan terpengaruh secara mendalam sehingga mengakibatkannya tidak 
mampu lagi berpikir rasional. Apabila emosi terlampau ditekan, terciptalah kebosanan. Bila emosi tak dikendalikan, emosi yang berkepanjangan akan menjadi sumber penyakit, seperti depresi berat, kecemasan berlebihan, amarah yang meluap-luap, dan gangguan emosional yang berlebihan (mania).

c. Motivasi. Aspek ketiga dari kecerdasan emosional adalah kemampuan individu untuk memotivasi diri ketika berada dalam keadaan putus asa, kemampuan berpikir positif dan menumbuhkan optimisme dalam hidupnya . Kemampuan hi akan membuat individu mampu bertahan dalam masalah yang membebaninya, mampu untuk terus berjuang ketika menghadapi hambatan yang besar, tidak mudah putus asa dan kehilangan harapan.

d. Empati. Kemampuan berempati yaitu kemampuan untuk mengetahui bagaimana perasaan orang lain dan ikut berperan dalam pergulatan dalam arena kehidupan (Goleman, 2000). Titchener (Goleman, 2000) menyatakan bahwa empati berasal dari semacam peniruan secara fisik atas beban orang lain, yang kemudian akan menimbulkan perasaan yang serupa dalam diri orang lain. Shapiro (Irwina, 2004) menjelaskan empati sebagai kemampuan untuk mengetahui dan memahami perasaan terdalam orang lain sehingga mampu bertenggang rasa dan mampu membaca, memahami perasaan, pikiran orang lain hanya dari bahasa non verbal, ekspresi wajah, atau intonasi suara orang lain. Empati dlbangun berdasarkan kesadaran diri. Bila diri semakln terbuka pada emosi maka seseorang akan semakin terampil dalam membaca perasaan.

e. Keterampilan Sosial. Keterampilan sosial merupakan kemampuan individu untuk membangun hubungan secara efektif dengan orang lain, mempertahankan hubungan sosial tersebut, serta menanganl konflik-konflik interpersonal secara efektif. Individu yang memiliki kemampuan ini akan mudah berinteraksi dengan orang lain, menginspirasikan kepercayaan pada orang lain, dan senantiasa bersikap saling menghormati hak-hak orang lain. Keterampilan sosial ini antara lain dapat ditingkatkan dengan mengembangkan keterampilan mendengarkan efektif dan berkomunikasi dengan efektif.

\section{Autisme}

Menurut Safaria (2005), beberapa gejala yang muncul pada anak autisme meliputi kegagalan membina hubungan interpersonal, hambatan dalam komunikasi verbal atau nonverbal dan adanya arasis nominasi.

a. Kegagalan membina hubungan interpersonal. Kegagalan membina hubungan interpersonal ini ditandai oleh kurangnya respon terhadap dan/atau kurangnya minat terhadap orang-orang atau anak-anak disekitarnya. Anak terlihat lebih suka menyendiri, asyik đengan dirinya sendiri, dan tidak peduli dengan kejadian-kejadian disekitamya. Perhatian anak hanya tertuju pada satu objek yang sedang dimainkannya. Anak juga kurang mampu melakukan kontak mata dengan ibu atau ayahnya. Jika nama anak tersebut dipanggil, seolaholah anak tidak mendengarnya. Anak juga kurang mampu menunjukkan respon ekspresi wajah yang wajar seperti tertawa atau tersenyum ketika digelitik atau diajak bermain oleh kedua orang fuanya.

b. Hambatan dałam komunikasi verbal atau non verbal. Anak autis kadang tidak mampu berbahasa sama sekali atau tidak mampu mengucapkan sepatah katapun. Apabila kemampuan berbahasa berkembang pada anak, biasanya ditandai oleh struktur tata bahasa yang tidak matang, ekolalia langsung atau yang tertunda, seperti mengucapkan kata-kata yang tidak artinya, pemutarbalikkan kata ganti orang, misalnya anak menggunakan kata ganti orang "kamu" padahal yang dimaksudnya adalah "saya".

c. Afasis nominasi. Afasis nominasi adalah ketidakmampuan memberikan nama 
pada benda-benda di sekelilingnya. Anak juga tidak mampu menggunakan istilah abstrak seperti cinta, kasih sayang, serta menggunakan bahasa meteforik, yaitu ucapan yang penggunaannya untuk diri sendiri serta memilikj arti yang tidak jelas. Sering kali anak juga kurang mampu menunjukkan komunikasi non verbal yang serasi.

Kecerdasan Emosional dan Depresi lbu yang Memilikl Anak dengan Gangguan Autisme

Orangtua yang mendapati diagnosis bahwa anaknya mengalami gangguan autisme akan menunjukkan reaksi emosi yang kuat karena memang persoalan ini sangat sulit dihadapi para orangtua. Orangtua dipaksa untuk berhadapan dengan keadaan yang baru serta menerima kenyataan yang menekan ini. Padahal setiap orang tua pasti mengharapkan anakanaknya mengalami tumbuh kembang yang wajar sehingga kehadiran anak yang autis dapat menjadi sumber kekecewaan dan menjadi beban emosional yang berat. Menurut Goleman (2000), emosi yang terlampau ditekan, terlampau ekstrim dan terus menerus akan menjadi sumber penyakit. Selain itu, emosi dengan intensitas yang tinggi dan melampaul titik wajar akan beralih menjadi kecemasan kronis, amarah yang tak terkendali, dan depresi.

Goleman (2000) menyatakan bahwa individu yang memiliki kecerdasan emosional yang baik akan memiliki kemampuan untuk menyadari dan memahami keseluruhan proses yang terjadi pada dirinya. la juga memiliki kemampuan mengelola emosi, kemampuan memotivasi diri sendiri, kemampuan menunjukkan empati serta keterampilan sosial. Dengan demikian dapat dikatakan bahwa ibu dengan kecerdasan emosional yang tinggi memiliki kesadaran diri dan memahami emosiemosinya lalu dapat mengelola emosinya. Ibu akan mempunyai motivasi untuk berjuang mengatasi emosinya dan berempati dengan orang dan dapat berinteraksi dengan orang lain dengan baik. Kemampuan yang baik dalam mengelola emosi memungkinkan ibu menjalankan rutinitas kehidupan dengan baik yang salah satunya adalah mendidik anak dengan gangguan autisme. Dengan demikian risiko menderita depresi akan menjadi lebih kecil karena dapat mengatasi reaksi-reaksi emosi yang muncul dengan baik dengan adanya kecerdasan emosional. Oleh karena itu, ibu dengan kecerdasan emosional yang lebih baik diperkirakan akan lebih rendah tingkat depresinya sekalipun anaknya didiagnosis mengalami gangguan autisme.

\section{Hipotesis}

Ada hubungan negatif antara kecerdasan emosional dengan depresi pada ibu yang memiliki anak gangguan autisme. Semakin tinggi kecerdasan emosional seseorang maka semakin ringan tingkat depresinya.

\section{Metode}

\section{Sub jek Penelitian}

Subjek dalam penelitian ini adalah 26 orang ibu yang memiliki anak berusia di bawah 12 tahun dengan gangguan autisme di Sekolah Terapi Autisme $X$ Pemilihan ibu sebagai subyek penelitian ini didasarkan pada pertimbangan bahwa ibu biasanya memiliki kelekatan yang lebih besar dengan anak. Selain itu, ibu adalah figur orang tua yang lebih sering bertemu dengan anak dalam upaya merawat dan mendidik anak tersebut.

\section{Alatukur}

Variabel kecerdasan emosional dan depresi diukur dengan menggunakan angket. Angket kecerdasan emosional yang digunakan merupakan modifikasi dari angket kecerdasan emosional yang diturunkan dari konsep kecerdasan emosional Goleman (Safaria, 2005). Angket ini telah dilihat validitas isi dan konstraknya, serta memiliki koefisien reabilitas alpha sebesar 0,9388 . Sedangkan angket depresi yang digunakan merupakan hasil modifikasi dari Beck Depression Inventory yang diturunkan dari Greist dan Jefferson (1984) dan Safaria (2005). Berdasarkan pengujlan reliabilitas didapatkan koefisien reabilitas aipha sebesar 0,9055 . 


\section{Prosedur Penelitian}

Angket dibagikan kepada para ibu yang sedang mengantar anaknya ke Sekolah Terapi Autisme $X$. Namun ada sebagian bu yang terpaksa membawa pulang angket karena tidak memiliki waktu untuk mengerjakannya di sekolah.

\section{MetodeAnalisis Data}

Pengujlan hipotesis menggunakan teknik korelasi Product Moment dari Pearson setelah melewati pengujian asumsi normalitas sebaran serta linearitas hubungan antara dua variabel. Uji normalitas sebaran untuk variabel kecerdasan emosional dan depresi dengan menggunakan Kolmogorov-Smirnov Z memberikan hasil sebesar 1,122 dan 0,868 $(p>0,05)$. Hal ini menunjukkan bahwa sebaran data kecerdasan emosional dan depresi mengikuti kurva normal. Sedangkan hasil uji linearitas hubungan menunjukkan hasil $F=0,898$ ( $p>0,05)$. Hal ini menunjukkan bahwa antara kecerdasan emosional dan depresi memilki hubungan yang bersifat linier.

\section{Hasll Penelltian}

Tabel 1 mendeskripsikan hasil tabulasi silang antara variabel kecerdasan emosional dan depresi.

Tabel 1.

Tabulasi Silang Kecerdasan Emosional dan Depresi

\begin{tabular}{llllll}
\hline Kecerdasan Emoslonal & \multicolumn{2}{l}{ Depresi (dalam \%) } & $\begin{array}{l}\text { Total } \\
\text { SR }\end{array}$ \\
\hline SRd & SR & R & S & B & $(\%)$ \\
Rd & 0 & 0 & 0 & 0 & 0 \\
S & 0 & 100 & 0 & 0 & 100 \\
T & 40 & 60 & 0 & 0 & 100 \\
ST & 60 & 40 & 0 & 0 & 100 \\
\hline
\end{tabular}

Ket Kecerdasan Emosional:

$S R d=$ Sangar Rendah

$R d=R e n d a h$

$S=$ Sedang

$T=$ Tinggi

$S T=$ Sangat Tinggi

Tabel 1 menunjukkan bahwa seluruh ibu dengan kecerdasan emosional rendah memiliki tingkat depresi yang ringan. Pada ibu-ibu yang memiliki kecerdasan emosional sedang, sebagian besar di antaranya (60\%) memiliki tlngkat depresi ringan, sedangkan sisanya (40\%) mengalami depresi sangat ringan cenderung normal. lbu-ibu yang memiliki kecerdasan emosional tinggi, hanya $40 \%$ mengalami depres| ringan, sedangkan sebagian besar lainnya (60\%) memiliki tingkat depresl sangat ringan cenderung normal. Pada ibu-ibu yang memiliki
Ket Depresi:

$S R=$ Sangat Ringan (cenderang nornal)

$R=$ Ringan

$S=$ Sedang

$B=B e r a l$

kecerdasan emosional sangat tinggi, seluruhnya (100\%) memiliki tingkat depresi sangat ringan cenderung normal. Hal ini mengindikasikan bahwa ada hubungan antara kecerdasan emosional dengan depresi.

Hasil uj korelasi Product Moment Pearson antara kecerdasan emosional dan depresi menunjukkan nilai $\mathrm{r}$ sebesar $-0,571$ ( $p<0,05$ ). Hal ini menumjukkan adanya hubungan negatif yang signifikan antara kecerdasan emosional dengan depresi pada bu yang memiliki anak autisme. Hal ini berarti 
semakin tinggi kecerdasan emosional yang dimiliki oleh ibu, semakin ringan tingkat depresi yang dialami. Demikian juga sebaliknya, semakin rendah kecerdasan emosional yang dimiliki oleh ibu maka semakin be rat depresi yang dialami.
Hasil penelitian tambahan yang penting adalah data deskriptif mengenai reaksi pertama ibu saat mengetahui diagnosa autisme pada anak serta tabulasi silang antara jenis pekerjaan ibu dengan depresi yang dítunjukkan pada Tabel 2 dan 3 .

Tabel 2.

Reaksi Pertama lbu Saat Mengetahui Diagnosa Autistik Anak

\begin{tabular}{lll}
\hline Reaksi & Frekuensi & Persentase \\
\hline Sedih & 15 & $57,77 \%$ \\
Syok & 10 & $38,46 \%$ \\
Cemas & 1 & $3,85 \%$ \\
Total & 26 & $100 \%$ \\
\hline
\end{tabular}

Tabel 2 menunjukkan bahwa sebagian besar reaksi pertama ibu saat mengetahui anaknya didiagnosis autisme adalah sedih $(57,77 \%)$.

Tabel 3 ,

Tabuiasi Silang Status Pekerjaan dan Depresi

\begin{tabular}{llllll}
\hline Status & \multicolumn{3}{c}{ Depresi (dalam \%) } & \multicolumn{2}{c}{ Total } \\
Pekerjaan & SR & R & S & B & $(\%)$ \\
\hline Pegawai Negeri & 100 & 0 & 0 & 0 & 100 \\
Pegawai Swasta & 100 & 0 & 0 & 0 & 100 \\
Tidak Bekerja & 57,89 & 42,11 & 0 & 0 & 100 \\
\hline
\end{tabular}

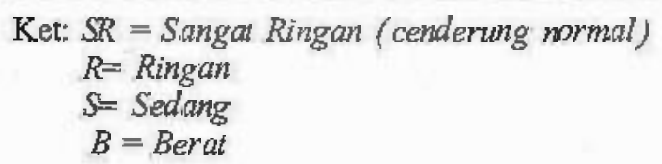

Tabel 3 menunjukkan bahwa seluruh ibu yang bekerja sebagai pegawai negert dan pegawai swasta memiliki tingkat depresi yang sangat ringan cenderung normal (100\%). Sedangkan ibu-ibu yang tidak bekerja (bu rumah tangga) memiliki tingkat depresi sangat ringan cenderung normal $(57,89 \%)$ dan ringan $(42,11 \%)$. Hasil ini memberikan indikasi adanya hubungan antara status ibu bekerja atau tidak dengan depresi.

\section{Pembahasan}

Data reaksi pertama ibu saat mengetahui anaknya didagnosis autis menunjukkan bahwa sebagian besar ibu memuncuikan reaksi sedih. Reaksi tersebut dapat dianggap sebagai reaksi yang wajar, karena ibu tentu saja mengharapkan anaknya dapat tumbuh kembang secara baik. Namun, sekalipun sebagian besar ibu memunculkan perasaan sedih sebagai 
reaksi pertama, data menunjukkan bahwa ibu-ibu dalam penelitian ini tidak mengalami depresi yang berat. Bahkan data menunjukkan bahwa ibu-ibu yang menjadi subyek dari penelitian memiliki tingkat depresi yang sangat ringan dan ringan. Hal ini menunjukkan bahwa reaksi kesedihan akibat hambatan dalam perkembangan anak serta harapan yang tidak terwujud tidak selalu berakhir pada kondisi depresif, sekalipun LaHaye (2005) menyebut kekecewaan sebagai salah satu penyebab depresi.

Hasil penelitian menunjukkan adanya hubungan negatif yang signifikan antara kecerdasan emosional dan depresi pada ibu dengan anak autis. Hal ini menegaskan bahwa semakin tinggi kecerdasan emosional yang dimiliki oleh ibu, semakin ringan depresi yang dialami. Demikian sebaliknya, semakin rendah kecerdasan emosional yang dimiliki oleh ibu, semakin berat depresi yang dialami.

Hasil penelitian inl dapat dijelaskan dengan melihat kembali aspek-aspek dalam kecerdasan emosional, terutama aspek kesadaran diri, kemampuan mengelola emosi dan kemampuan memotivasi diri sendiri. lbu-ibu yang memilikl kecerdasan emosional yang tinggi akan lebih peka daiam menyadari perasaan-perasaannya dan pikiran-pikirannya yang terkait dengan kenyataan memiliki anak autisme. Adanya kesadaran diri juga memungkinkan para ibu tersebut mengenali emosi atau perasaan negatif yang muncul, yang menjadi dasar penting untuk melakukan pengelolaan emosi. Adanya kemampuan mengeioia emosi memungkinkan para ibu untuk mengendalikan diri, sehingga tidak larut dan terbawa terus dalam arus emosi yang negatif. Seperti yang disampaikan oleh Goleman (2000), emosi negatif yang tidak dikendalikan akan menjadi sumber penyakit misalnya depresi berat, kecemasan berlebihan, amarah yang meluap-luap, dan gangguan emoslonal yang berlebihan (mania). Dengan demikian ibu-ibu yang memiliki kecerdasan emosional yang lebih tinggi, akan lebih mampu untuk mengelola emosinya sehingga emosinya lidak berkepanjangan. Sebagai akibatnya, efek-efek negatif dari emosi negatif yang berkepanjangan itu dapat dihindari. Ketika harapan tidak tercapal dan perasaan putus asa muncul menghadapi kenyataan pada anak, ibu-ibu dengan kecerdasan emosional yang lebih tinggi akan lebih mampu memotivasi diri, sehingga mereka lebih mampu bertahan daiam masalah yang membebani, tidak mudah putus asa, dan memiliki daya juang yang lebih besar.

Tabulasi silang antara status pekerjaan dengan depresi (Tabel 2) menunjukkan indikasi adanya hubungan antara status ibu bekerja (baik sebagai pegawai negeri maupun pegawai swasta) atau tidak bekerja dengan depresi. Ada beberapa kemungkinan penjelasan akan data ini. Pertama, Huriock (1992) menyatakan bahwa beberapa wanita berusaha untuk menghindari rasa frustrasi dan bosan dengan bekerja sesuai minat. Terkait dengan hasil dalam penelitian Inl, para ibu yang bekerja mungkin saja mendapatkan kesempatan untuk terbebas dari rasa frustrasi dengan kondisi anak serta rasa bosan yang mungkin muncui dari rutinitas kegiatan rumah tangga, menghadapi dan merawat anak dalam kurun waktu yang panjang. Kedua, lbu yang bekerja memiliki relasi sosial yang lebih luas, sehingga memungkinkan terbangunnya dukungan sosial yang lebih luas. Adanya dukungan sosial memberikan kekuatan tersendli bagi para ibu dalam menghadapi kenyataan hidup yang mengecewakan atau memunculkan stres. Kemungkinan ketiga, ibu-ibu yang tidak bekerja mengembangkan identitas diri yang banyak terkait dengan kondisi anak. Sedangkan ibu-ibu yang tidak bekerja mungkin mengembangkan identitas diri yang tidak hanya terkait dengan kondisi anak, namunjuga dengan banyak hal lainnya misalnya prestasi-prestasi yang diraih, kemampuan aktualisasi diri, serta penghargaan orang lain yang lebih dimungkinkan diperoleh pada situasi kerja. Untuk mendapatkan pemahaman yang lebih jelas mengenai data ini, penelitian lebih lanjut untuk meneiusuri hubungan antara status bekerja ibu dan depresi perlu dilakukan. 
Berdasarkan uraian d atas, ada dua simpulan penting yang dapat diberikan: (1) Semakin tinggi kecerdasan emosional seseorang, semakin ringan tingkat depres| yang dialami. Semakin rendah kecerdasan emosional seseorang, semakin berat tingkat depresi yang dialami. (2) Ada indikasi hubungan antara status pekerjaan dan depresi. Melihat adanya hubungan negatif antara kecerdasan emosional dan depresi, maka upaya-upaya untuk meningkatkan kecerdasan emosional para ibu dari anak penderita autisme sangat diperlukan. Lembaga-lembaga terapi autisme dapat mengadakan pelatih an-pelatiha $n$ pengembangan kecerdasan emosional bagi para ibu anak autis. Pelatihan tersebut diharapkan dapat mengembangkan kecerdasan emosional sehingga kemampuan mengenali perasaan diri, mengelola emosi serta memotivasi diri juga semakin meningkat. Saran lain terkait dengan penelitian lebih lanjut guna menelusuri hubungan antara status bekerja ibu dan depresi.

\section{Daftar Pustaka}

Emmanuell, Y. 2004. "Hubungan antara Depresi dengan Perilaku Agresi pada Penderita Ketergantungan NAPZA" Skripsi. Surabaya: Fakultas Psikologi Universitas Surabaya.

Goleman, D. 2000. Emotional Intelligence: Kecerdasan Emosional. Jakarta: Penerbit PT Gramedia Pustaka Utama.
Greist, J. H., \& Jefferson, J. W. 1984. Depresi dan Penyembuhannya. Alih bahasa : Cahya Subrata. Jakarta: Penerbit BPK Gunung Mulia.

Hurlock, E. B. 1992. Psikologi Perkembangan. Alih bahasa : Istiwidayanti, \& Soedjarwo. Jakarta: Penerbit Erlangga

Irwina,. 2004. "Hubungan antara Kecerdasan Emosional dengan Stres Kerja Karyawan ${ }^{\alpha}$ Skripsi. Surabaya: Fakultas Psikologi Universitas Surabaya.

Kartono, K, \& Gulo, D. 2000. Kamus Psikologi. Bandung: Penerbit Pionir Jaya.

Kuwanto, L., \& Natalia, J. 2001. Terapi musik pada anak autisme. Anima. vol.16, no.2, halaman 190-214.

LaHaye, T. 2005. Bagaimana Mengatasi Depresi. Alih bahasa : Harso Sutandyo. Batam: Penerbit Gospel Press.

Safaria, T. 2005. Autisme: Pemahaman baru untuk hidup bermakna bagi orang tua. Yogyakarta: PenerbitGraha $\| \mathrm{m}$.

Sheeve, C. M. 1991. Mengenal dan Mengatasi Depresi. Alih bahasa: Anum Gayatri. Jakarta: PenerbitArcan 